\title{
Performance of different upland cotton varieties under the climatic condition of Lasbella Uthal Balochistan
}

\author{
Sultan Ahmed ${ }^{1}$, Shahab-u-din ${ }^{2 *}$, Tassawar Hussain Malik ${ }^{3}$, Muhammad \\ Rashid $^{4}$, Nazeer Ahmed ${ }^{2}$, Shafique Ahmed ${ }^{2}$ and Abdul Qadir ${ }^{5}$ \\ 1. Cotton Research Station (PCCC) LUAWMS Uthal, Balochistan-Pakistan \\ 2. Agricultural Research Institute (BAR\&DC), PARC, Turbat-Pakistan \\ 3. Agricultural Research, Pakistan Central Cotton Committee, Multan-Pakistan \\ 4. Department of Agronomy, Lasbella University of agriculture, water and Marine Science Uthal, Balochistan- \\ Pakistan \\ 5. Horticulture Research Institute (BAR\&DC), PARC, Khuzdar-Pakistan \\ *Corresponding author's email: shahabkashani64@gmail.com \\ Citation \\ Sultan Ahmed, Shahab-u-din, Tassawar Hussain Malik, Muhammad Rashid, Nazeer Ahmed, Shafique Ahmed and \\ Abdul Qadir. Performance of different upland cotton varieties under the climatic condition of Lasbella Uthal \\ Balochistan. Pure and Applied Biology. Vol. 8, Issue 1, pp518-522. http://dx.doi.org/10.19045/bspab.2018.700211 \\ \begin{tabular}{llll}
\hline \hline Received: 03/09/2018 & Revised: 10/12/2018 & Accepted: 13/12/2018 & Online First: 17/12/2018 \\
\hline \hline
\end{tabular}
}

\section{Abstract}

A trial was conducted at Cotton Research Station Lasbela for testing and evaluating the yield and fiber performance of different commercial cotton varieties so that on the basis of the results best varieties can be recommended for general cultivation in the area. Eight best Bt and non-Bt cotton varieties of different organizations were sown under the climatic condition of Lasbela. It was concluded that CRIS-129 obtained maximum seed cotton yield (3850 kg ha-1) followed by CRIS342 (3592 kg ha $\left.{ }^{-1}\right)$ and Sindh-1 (3518 kg ha-1). For bolls per plant CRIS-129 formed maximum number of bolls (43.0) per plant fallowed by CRIS-342 (40.2) and Sindh-1 (39.0). Maximum boll weight $(3.7 \mathrm{~g}$ ) was weighted in variety MNH-886. Whereas, CRIS-342 and BH-178 and CEMB33 were the second which gave ( $3.5 \mathrm{~g}$ ) boll weight. CEMB-33 ginned highest lint percentage (41.5) followed by MNH-886 (40.0) and Sadori (38.6). CRIS-342 produced longer staple length (29.0 $\mathrm{mm})$ followed by BH-178 $(28.3 \mathrm{~mm})$ and Sadori $(28.2 \mathrm{~mm})$. Regarding mike value CRIS-129 and Sadori produced better mike value $\left(4.4 \mu \mathrm{inch}^{-1}\right)$ as compared to other varieties. Among all the varieties CRIS-129 showed maximum fiber strength (35.0 g/tex $\left.{ }^{-1}\right)$ followed by CRIS-134 (34.2 $\left.\mathrm{g} / \mathrm{tex}^{-1}\right)$ and CRIS-342 $\left(32.5 \mathrm{~g} / \mathrm{tex}^{-1}\right)$. On the basis of present findings, it was concluded that upland cotton cultivar 'CRIS-129' showed promising results for getting higher seed cotton yield followed by CRIS-342 and Sindh-1. The cotton cultivar 'CRIS-129' is recommended to cotton growers for cultivation under climatic condition of Lasbella, Uthal Balochistan.

Keywords: Fiber strength; Lint (\%); Seed cotton yield

\section{Introduction}

Textile industry globally focused on fibre crop that is cotton, In Pakistan cotton not only meet the fiber demand of the textile industry but also provide $70 \%$ locally produced edible oil for the community [1]. Cotton crop has $1 \%$ share in GDP and contributes $5.2 \%$ in agriculture value addition. During 2016-17 
the cotton production in the country was stood at 10.074 million bales on an area of 2917 thousand hectares [2].

Punjab and Sindh are the leading province in cotton production, where Balochistan province is a new window for cotton cultivation mostly land is barren and ideal environmental condition for cotton cultivation, especially coastal area of the province have ideal climate for long and extra-long staple cotton production, hence it is very much necessary to develop production technology and develop suitable varieties that produced higher seed cotton yield along with better fiber traits.

To find out the best performance of a cultivar, a test for its adoptability and various growth characteristics is imperative. Selection based on yield components may help to identify and develop lines having improved and more stable yield [3].

The main objective of the study was to determine the best commercial upland cotton cultivar which produce highest seed cotton yield under this climatic condition. Such study can be instrumental in producing the genotypes those are favourable in seed cotton yield enhancement and other characters.

\section{Materials and Methods}

The study was conducted at the experimental fields of Lasbella, Uthal Balochistan during 2017-18. For this purpose, eight Bt. and NonBt. cotton verities viz., CRIS-134, CRIS-342, CRIS-129, SADORI, Sindh-1, BH-178, MNH-886 and CEMB-33 were sown under the climatic condition of Lasbella using hand drilling method. All the agronomic and cultural practices were performed throughout the experiment. After maturity of the crop the observations were taken on seed cotton yield $\left(\mathrm{kg} \mathrm{ha}^{-1}\right)$, bolls plant ${ }^{-1}$, bolls weight $(\mathrm{g})$, lint $(\%)$, staple length $(\mathrm{mm})$, mike value $\left(\mu\right.$ inch $^{-}$ $\left.{ }^{1}\right)$ and fiber strength $\left(G t^{-1}\right)$. Finally, the collected data for each cultivar were utilized for statistical analysis of variance (ANOVA) and least significant difference test to know the significance level between the genotypes. Results and discussion

Seed cotton yield $\left(\mathrm{kg} \mathrm{ha}^{-1}\right)$ : Analysis of variance indicated that all varieties were highly significant $(\mathrm{P}=0.01)$ for seed cotton yield per hectare (Table 1). The results (Table-2) indicates that genotype CRIS-129 produced significantly higher seed cotton yield (3850 kg ha-1) followed by CRIS-342 (3592 kg ha-1), Sindh-1 (3518 kg ha-1), MNH886 (3470 kg ha-1), SADORI (3452 kg ha-1), CRIS-134 (3275 kg ha-1) and BH-178 (3211 $\left.\mathrm{kg} \mathrm{ha}^{-1}\right)$, respectively. Significantly lowest seed cotton yield $\left(3150 \mathrm{~kg} \mathrm{ha}^{-1}\right)$ was observed for genotype 'CEMB-33'. There was significant differences in seed cotton yield among the upland cotton genotypes. The above findings of the current study are in accordance with the previous studies [4-6].

\section{Bolls/plant (g)}

Analysis of variance indicated that all varieties were highly significant $(\mathrm{P}=0.01)$ for number of bolls per plant (Table 1). The results (Table 2) indicates that genotype CRIS-129 produced significantly $(\mathrm{p}<0.05)$ maximum bolls / plant (43.0) followed by CRIS-342 (40.2), Sindh-1 (39.0), MNH-886 (37.0), CRIS-134 (36.1) and SADORI (35.1), respectively. Significantly $(\mathrm{p}<0.05)$ minimum bolls / plants (34.1 and 34.0) were noted for genotypes CEMB-33 and BH-178. There was significant difference in bolls / plant between the upland cotton genotypes. The result of this investigation are parallel with the findings of Copur, Anwar et al., Moser et al. and Ehsan et al. [5, 7-9].

\section{Bolls weight (g)}

Analysis of variance indicated that all varieties were highly significant $(\mathrm{P}=0.01)$ for boll weight (Table 1). The results (Table 2) indicates that genotype $\mathrm{MNH}-886$ received slightly more bolls weight $(3.7 \mathrm{~g})$ followed by CRIS-342 (3.5 g), BH-178 (3.5 g), CEMB-33 (3.5), CRIS-134 (3.4 g) and SADORI (3.3), respectively. Minimum bolls 
weight (3.2 g) was noted for genotypes CRIS-129 and Sindh-1. There was nonsignificant difference in bolls weight between the upland cotton genotypes. Similar results are reported by (Hofs et al., and Anonymous $[9,10]$.

Lint (\%)

Analysis of variance indicated that all varieties were highly significant $(\mathrm{P}=0.01)$ for lint percentage (Table 1). The results (Table 2) indicates that genotype CEMB-33 received significantly $(\mathrm{p}<0.05)$ higher lint (41.5\%) followed by MNH-886 (40.0\%), SADORI (38.6\%), CRIS-134 (38.3\%), CRIS-129 (37.9\%) and Sindh-1 (37.0\%), respectively. Significantly lower lint $(36.8 \%)$ was equally recorded for genotypes CRIS134 and $\mathrm{BH}-178$. There was significant difference in lint percentage between the upland cotton genotypes. The findings agree with the study of Usman et al., Wang et al., Arshad et al. [11-13].

Table 1. ANOVA for seed cotton yield and other traits

\begin{tabular}{|c|c|c|c|c|c|c|c|c|}
\hline SOV & df & $\begin{array}{c}\text { Seed } \\
\text { cotton } \\
\text { Yield }\end{array}$ & $\begin{array}{c}\text { Bolls/ } \\
\text { Plant }\end{array}$ & $\begin{array}{c}\text { Boll } \\
\text { weight }\end{array}$ & $\begin{array}{c}\text { Lint } \\
\text { Percenta } \\
\text { ge }\end{array}$ & $\begin{array}{c}\text { Staple } \\
\text { Length }\end{array}$ & $\begin{array}{c}\text { Mike } \\
\text { Value }\end{array}$ & $\begin{array}{c}\text { Fiber } \\
\text { Strength }\end{array}$ \\
\hline Replications & 2 & 0.14 & 0.093 & 0.002 & 1.45 & 1.1 & 0.03 & 1.1 \\
\hline Genotype & 7 & $56.87^{* *}$ & $47.65^{* *}$ & $0.21^{* *}$ & $8.75^{* *}$ & $8.9^{* *}$ & $0.98^{*}$ & $9.33^{* *}$ \\
\hline Error & 14 & 25 & 0.034 & 0.002 & 1.55 & 2.1 & 0.34 & 3.1 \\
\hline
\end{tabular}

Table 2. Comparison of means for yield and other Yield related traits among varieties

\begin{tabular}{|c|c|c|c|c|c|}
\hline Sr. No & Verities & $\begin{array}{c}\text { Seed cotton Yield } \\
\left(\mathrm{kgha}^{-1}\right)\end{array}$ & Bolls/ Plant & $\begin{array}{l}\text { Boll weight } \\
\text { (g) }\end{array}$ & Lint $(\%)$ \\
\hline 1 & CRIS-134 & 3275 & 36.1 & 3.4 & 36.8 \\
\hline 2 & CRIS-342 & 3592 & 40.2 & 3.5 & 38.3 \\
\hline 3 & CRIS-129 & 3850 & 43.0 & 3.2 & 37.9 \\
\hline 4 & SADORI & 3452 & 35.1 & 3.3 & 38.6 \\
\hline 5 & Sindh-1 & 3518 & 39.0 & 3.2 & 37.0 \\
\hline 6 & BH-178 & 3211 & 34.0 & 3.5 & 36.8 \\
\hline 7 & MNH-886 & 3470 & 37.0 & 3.7 & 40.0 \\
\hline 8 & CEMB-33 & 3150 & 34.1 & 3.5 & 41.5 \\
\hline \multicolumn{2}{|c|}{ LSD $0.05 \%$} & 36.6 & 12.5 & 0.2 & 10.2 \\
\hline
\end{tabular}

\section{Staple length (mm)}

Analysis of variance indicated that all varieties were highly significant $(\mathrm{P}=0.01)$ for staple length (Table 1). The results (Table 3) indicates that genotype CRIS-342 received significantly $(\mathrm{p}<0.05)$ tallest staple length (29.0 mm) followed by BH-178 $(28.3 \mathrm{~mm})$, SADORI $(28.2 \mathrm{~mm})$, Sindh-1 $(28.0 \mathrm{~mm})$, MNH-886 (28.0 mm) and CEMB-33 (27.9 $\mathrm{mm})$, respectively. Significantly smallest staple length (27.5) was equally recorded for genotypes CRIS-134 and CRIS-129. There was significant difference in staple length between the upland cotton genotypes. Results of the present experiment are fully agreed with those of Usman et al., Ashokkumar and Ravikesavan [13, 14].

Mike value $\left(\boldsymbol{\mu}\right.$ inch $\left.^{-1}\right)$

Analysis of variance indicated that all varieties were highly significant $(\mathrm{P}=0.05)$ for Mike Value (Table 1). Micronaire value indicates fibre fineness which is an important parameter from industrial point of view. It is evident from analysis of variance that there were significant differences among various varieties regarding micronaire value. The results (Table 3) indicates that genotype CRIS-134, CRIS-342 and BH-178 received 
maximum mike value $\left(4.8 \mu\right.$ inch $\left.^{-1}\right)$ followed by CEMB-33(4.6 $\mu$ inch $\left.^{-1}\right)$, Sindh-1 $(4.5 \mu$ inch $\left.^{-1}\right)$ and MNH-886 (4.5 $\mu$ inch $\left.^{-1}\right)$, respectively. Minimum mike value $(4.4 \mu$ inch $^{-1}$ ) was equally recorded for genotypes CRIS-129 and SADORI. There was nonsignificant difference in mike value between the upland cotton genotypes. These results supported by Copur and Usman et al, $[5,11]$ communicated similar findings by reporting significant variations among cultivars with respect to fibre fineness.

Fiber strength (G tex $\left.{ }^{-1}\right)$

Analysis of variance indicated that all varieties were highly significant $(\mathrm{P}=0.01)$ for
Fiber strength (Table 1). The results (Table 3) indicates that genotype CRIS-129 received significantly $(\mathrm{p}<0.05)$ higher fiber strength $\left(35.0 \mathrm{G} \mathrm{tex}^{-1}\right)$ followed by CRIS-134 $(34.2 \mathrm{G}$ tex $\left.^{-1}\right)$, CRIS-342(32.5 G tex $\left.{ }^{-1}\right)$, MNH-886 (31.8 G tex $\left.{ }^{-1}\right)$, SADORI (30.8 $\mathrm{G}$ tex $\left.{ }^{-1}\right)$, Sindh-1 (30.6 G tex ${ }^{-1}$ ) and CEMB-33 (30.1 G tex $\left.^{-1}\right)$, respectively. Significantly lower fiber strength (29.9 $\mathrm{G}$ tex $\left.^{-1}\right)$ was recorded for genotype $\mathrm{BH}-178$.There was significant difference in fiber strength between the upland cotton genotypes. Results are supported by Usman et al. and Basbağ and Temiz, [13, 15].

Table 3. Comparison of means among varieties fiber related parameters

\begin{tabular}{|c|c|c|c|c|}
\hline Sr. No & Verities & $\begin{array}{c}\text { Staple length } \\
(\mathbf{m m})\end{array}$ & $\begin{array}{c}\text { Mike Value } \\
\left(\boldsymbol{\mu} \text { inch }^{-1}\right)\end{array}$ & $\begin{array}{c}\text { Fiber strength } \\
\left(\mathbf{G ~ t e x ~}^{\mathbf{1}}\right)\end{array}$ \\
\hline 1 & CRIS-134 & 27.5 & 4.8 & 34.2 \\
\hline 2 & CRIS-342 & 29.0 & 4.8 & 32.5 \\
\hline 3 & CRIS-129 & 27.5 & 4.4 & 35.0 \\
\hline 4 & SADORI & 28.2 & 4.4 & 30.8 \\
\hline 5 & Sindh-1 & 28.0 & 4.5 & 30.6 \\
\hline 6 & BH-178 & 28.3 & 4.8 & 29.9 \\
\hline 7 & MNH-886 & 28.0 & 4.5 & 31.8 \\
\hline 8 & CEMB-33 & 27.9 & 4.6 & 30.1 \\
\hline \multicolumn{2}{|r|}{} & $\mathbf{1 0 . 2}$ & $\mathbf{1 . 0}$ & $\mathbf{1 1 . 4}$ \\
\hline
\end{tabular}

\section{Conclusions}

On the basis of present findings, it was concluded that cotton cultivar 'CRIS-129' showed promising results for getting higher seed cotton yield followed by CRIS-342 and Sindh-1. The cotton cultivar 'CRIS-129' is recommended for the cotton growers to cultivate it under climatic condition of Lasbella, Uthal Balochistan.

\section{Authors' contributions}

Conceived and designed the experiments: S Ahmed \& M Rashid, Performed the experiments: S Ahmed \& A Qadir, Analyzed the data: $\mathrm{T}$ H Malik, \& SH Ahmed, Contributed materials/ analysis/ tools: S Ahmed, N Ahmed, Wrote the paper: S Din \& S Ahmed.

\section{References}

1. Hanif CM, Hassan SW, Mehdi SS, Iqbal $K$ \& Hayat F (2005). Performance of candidate cotton genotypes in respect of yield and yield components. Indus Cottons 2(2): 151-154.

2. Anonymous (2017-18). Agriculture statistics of Pakistan, Ministry of Finance, Govt of Pakistan.

3. Bourland FM (2004). Overview of the University of Arkansas cotton breeding program. In: Proceedings, Belt wide Cotton Prod. Res. Conf. San Antonio, Tex. National Cotton Council, Memphis, Tenn. CD-ROM.

4. Khan NU, Hassan G, Marwat KB, F, Batool S, Makhdoom K, Khan I, Khan IA \& Ahmed W (2009). Genetic 
variability and heritability in upland cotton. Pak J Bot 41(4): 1695-1705.

5. Copur O (2006). Determination of yield and yield components of some cotton cultivars in semi-arid conditions. Pak $J$ Biol Sci 9(14): 2572-2578.

6. Hofs JL,Hau B \& Marais D (2006). Boll distribution patterns in $\mathrm{Bt}$ and non- $\mathrm{Bt}$ cotton cultivars: Study on commercial irrigated farming systems in South Africa. Field Crop Res 98(2-3): 203-209.

7. Anwar AM, MI Gill, DMuhammad \& MN Afzal (2002). Evaluation of cotton varieties at different doses of nitrogen fertilizer. The Pak Cottons 46(1-4): 3541.

8. Moser HS, McCloskey WB \& Silvertooth JC (2000). Performance of transgenic cotton varieties in Arizona. In P Dugger, D Richter, P Dugger, \& D Richter (Eds.), Proceedings Beltwide Cotton Conferences pp 497-499.

9. Ehsan F, Ali A, Nadeem MA, Tahir M \& Majeed A (2008). Comparative Yield Performance of New Cultivars of Cotton (Gossypium hirsutum L.). Pak J life Soc Sci 6(1): 1-3.

10. Anonymous (1997). Preservation and utilization of germplasm in cotton.
Southern Coop Series Bulletin No 386.

11. Usman K, Ayatullah, Khan N \& Khan S (2016). Genotype-by-sowing date interaction effects on cotton yield and quality in irrigated condition of Dera Ismail Khan, Pakistan. Pak J Bot 48(5): 1933-1944.

12. Wang C, Isoda A \& Wang P (2004). Growth and yield performance of some cotton cultivars in Xinjiang, China, an arid area with short growing period. $J$ of Agro and Crop Sci 190(3): 177-183.

13. Arshad M, Afzal M, Khan MI \& Mahmood R (2003). Performances of newly developed cotton strains for economic and fiber traits in national coordinated varietal trials. Pak J of Sci and Ind Res 46(5): 373-375.

14. Ashokkumar K \& Rajasekaran R (2011). Morphological diversity and per se performance in upland cotton (Gossypium hirsutum L.). J of Agri Sci 3(2): 107113.

15. Basbag S \& Temiz MG (2004). Determinations of some agronomical and technological properties on cotton having different colors fiber. J of Agron 3(4): 301-304. 